\title{
DUSP22 wt Allele
}

National Cancer Institute

\section{Source}

National Cancer Institute. DUSP22 wt Allele. NCI Thesaurus. Code C49419.

Human DUSP22 wild-type allele is located in the vicinity of 6p25.3 and is approximately 59 $\mathrm{kb}$ in length. This allele, which encodes mitogen-activated protein kinase phosphatase $x$ protein, is involved in the dephosphorylation of phosphoproteins. 